\title{
The Impact of Perceived Service Quality on Students' Intentions in Higher Education in a Jordanian Governmental University
}

\author{
Naseem M. Twaissi ${ }^{1}$ \& Mohammad H. Al-Kilani ${ }^{1}$ \\ ${ }^{1}$ Department of Business Administration, Al-Hussein Bin Talal University, Jordan \\ Correspondence: Naseem M. Twaissi, Department of Business Administration, Al-Hussein Bin Talal University, \\ Jordan. E-mail: naseem_petra@ hotmail.com
}

Received: February 17, 2015

Accepted: March 12, 2015

Online Published: April 25, 2015

doi:10.5539/ibr.v8n5p81

URL: http://dx.doi.org/10.5539/ibr.v8n5p81

\begin{abstract}
This study aims to investigate the impact of perceived service quality regarding the academic side on students' behavior intentions in a Jordanian governmental university. A survey was conducted on a stratified systemic random sample of 841 students, yielding 572 participants with $68 \%$ response rate. The findings show that perceived service quality as well as the tangibility and assurance dimensions affect students' intentions of recommending to study at their university. Further, perceived service quality as well as the tangibility dimension affects students' intentions of moving to study at another university. The results also proved that the two genders perceived the tangibility dimension of service quality differently, as males reported higher assessment. The study has provided important insights into service quality and behavior intentions in the field of Higher Education.
\end{abstract}

Keywords: service quality, student behavior intentions, higher education, university, Jordan

\section{Introduction}

Student retention has become a challenging problem for the academic community, thus effective measures for student retention must be implemented in order to increase the retention of qualified students at higher education institutions (Lau, 2003). Providing good service quality to customers helps retaining them and attracting new ones, as well as encouraging positive recommendation (Negi, 2009; Ladhari, 2009). Thus, there has been much interest in exploring the relationship between service quality and customer behavioral outcomes, for which a researcher is supposed to assess service quality. Therefore, higher education institutions have to continue to deliver a high quality service and satisfy students in order to succeed in a competitive service environment as DeShields et al. (2005) argued.

There is clear evidence on the importance of service quality in higher education institutions according to many studies (e.g., Angell et al., 2008; Ham \& Hayduk, 2003). The applicability and adaptation of the service quality concepts and evaluation models into the higher education sector have received much attention in recent years and are considered the main goal to achieve (Temizer \& Turkyilmaz, 2012). Baron et al. (2009, p. 167) revealed that: "Service quality is the single most researched area in services marketing to date."

A greater attention has been paid to service quality by marketing academics and practitioners in the past few decades. Academics, in particular, were very much interested in the measurement of service quality (e.g., Cronin \& Taylor, 1992; Parasuraman et al., 1985, 1988, 1994; Negi, 2009).

This study was conducted in a Jordanian governmental University to address two research questions and to achieve two objectives. The first research question was: "Does perceived service quality vary between the two genders?" The second question was: "Does perceived service quality influence students' behavior intentions regarding recommending to study at their university and to move to another university?"

The first objective of this study was to explore the differences between the two genders in perceiving service quality. The other objective was to investigate the impact of perceived service quality on students' behavior intentions in terms of recommending their university and moving to another university. The perceived service quality was regarding the academic side. Differences in perceived service quality and its impact were assessed in terms of each service quality dimension as well as the overall perception. 


\section{Literature Review}

\subsection{Service Quality Definition}

Defining quality in Higher Education has proved to be a challenging task (Khodayari \& Khodayari, 2011). As it is a complex and versatile concept and there is a lacking in appropriate definition in higher education (Harvey \& Green, 1993). It is suggested by Cheng and Tam (1997) that education quality is a rather vague and controversial concept.

By defining service quality, companies will be able to deliver services with higher quality level presumably resulting in increased customer satisfaction (Ghylin et al., 2008, p. 76). Service quality is defined as the overall assessment of a service by the customer (Eshghi et al., 2008, p. 121). Parasuraman et al. (1988, p. 15) defined service quality as 'a global judgment or attitude relating to the overall excellence or superiority of the service'. Further, Rowley (1997) defined the perceived quality as the customer's assessment about an entity's overall excellence or superiority. Furthermore, Athiyaman (1997) defines perceived service quality "as an overall evaluation of the goodness or badness of a product or service".

Consequently, there are many ways to define quality in Higher Education and each definition has its own criteria and perspective (Harvey \& Green, 1993). Takalo et al. (2013) stated that education quality refers to the characteristics of education factors and using capabilities and potentials of those factors, explicit and implicit expectations and needs of educational customers can be met and their expectations can be achieved.

\subsection{Service Quality Evaluation Methods}

There are different measurements used to measure quality services in Higher Education. There are six quality dimensions in Higher Education as proposed by Owlia and Aspinwall, (1996). These dimensions are tangibility (adequate equipment and facilities), competence (teaching expertise, practical and theoretical knowledge), attitude (understanding students' needs, courtesy, personal attention, willingness to help, etc.), content (practical relevance of curriculum, being cross-disciplinary, flexibility of knowledge, etc.), delivery (effective presentation, feedback from students, encouraging students, etc.), reliability (trustworthiness, handling complaints, solving problems) (Owlia \& Aspinwall, 1996).

On the other hand, Zineldin (2007) stated that the measurement of students' perceptions about the quality of service offered by a university can reflect the level of overall students' satisfaction within the institution. He focused on five quality dimensions in his proposal. They were object quality, process quality, infrastructure quality, interaction and communication quality, and atmosphere quality (Zineldin, 2007).

Further, using both qualitative and quantitative measures, Abdullah (2006) developed and validated HEdPERF, a method to evaluate service quality specifically designed for Higher Education sector.

Beside these methods of evaluation, SERVQUAL is recognized as an implemented and experienced instrument that has been successfully applied in various different contexts (Buttle, 1996). It is one of the most famous broadly used models to evaluate quality developed by Parasurman et al. (1988). SERVQUAL comprises five dimensions namely- tangibles, reliability, responsiveness, assurance and empathy. This evaluation method was utilized as some researchers recommended to be used in higher education institutions (e.g., Seymour, 1992; Arambewela \& Hall, 2006; Dado et al., 2012; Ibrahim et al., 2013; Ilyasi et al., 2013; Koni et al., 2013).

The majority of studies in Higher Education service quality have focused on student's point of view more than the perspectives of academic and administration staff (Khodayayari \& Khodayari, 2011). Owlia and Aspinwall (1996) shed the light on the role of students in Higher Education. Harvey (2001, p. 4) stated that "institution-wide student feedback about the quality of their total educational experience is an area of growing activity in Higher Education institutions around the world".

In the same vein, SERVQUAL was used by several researchers in HEIs to capture students' point of view (e.g., Seymour, 1992; Tahmouri et al., 2010). Saadati (2012) measured service quality of US education institutions from student points of view. Further, there are many studies utilized SERVQUAL model for measuring customer perception (Brochado, 2009; Lee \& Tai, 2008).The current study used SERVQUAL to measure the services quality in Higher Education through students' perspectives only.

In addition, Hill (1995) recognized the difficulty of measuring students' expectations. Hill confirmed that many students do not even know what expectations they have, or which expectations they had about the service provided.

It is found by some researchers that measurement of expectations does not supply exclusive information for estimating service quality; they argued that performance-only assessment has already taken into account much of 
this information (Babakus \& Boller, b1992). Therefore, the current study utilized SERVQUAL model to evaluate students' perceived service quality in Higher Education without their expectation.

\subsection{The Relationship between Services Quality and Demographic Attributes}

\subsubsection{Gender}

As females and males have different needs and wants, they are expected to be concerned and subsequently perceive service quality differently (Bowie \& Buttle, 2004). Hence, females are expected to assess service quality lower than males, which was proved elsewhere. For example, Snipes et al. (2006) found that females evaluate service quality consistently lower than do males; females expect a higher service quality and consider this more crucial than do their male counterparts.

These differences were also reported regarding different dimensions of service quality. For example, women generally have higher expectations concerning the importance of service delivery than do men particularly in the tangible dimension (Ross et al., 1999). Further, Lee et al. (2012) concluded that a significant difference in the perception of responsiveness between the female and male customers in the senior age group. Specifically, female mature customers are more likely to be concerned with responsiveness than are the male mature customers.

This leads to the first two research hypotheses:

HA1: There are differences in the perceived service quality between the two genders.

HA2: There are differences in the perceived five dimensions of service quality between the two genders.

\subsection{Perceived Services Quality and Behavior Intentions}

The relationship between perceived service quality and several behavior intentions has been proofed in numerous studies (e.g., Boulding et al., 1993; Zeithaml et al., 1996; De Ruyter et al., 1998; Lee \& Cunningham, 2001; Gracia et al., 2011; Ha \& Jang, 2012).

Zeithaml et al. (1996) proposed a model for the consequences of perceived quality, through which they differentiated between favorable and unfavorable behavior intentions. Behavior intentions include intention to recommend for others (e.g., Zeithaml et al., 1996; Bloemer et al., 1999), and intention to repurchase (e.g., Alexandris et al., 2002; Ranaweera \& Neely, 2003; Fen \& Lian, 2005; Nadiri \& Hussain, 2005; Negi, 2009). These two behavior intentions are addressed in this study.

The first behavior intention is the intention of recommending for others. Service recommendation, also referred to as advocacy and word-of-mouth in the customer service literature, which can be either positive or negative (Bontis et al., 2007).

The other behavior intention is labeled repurchase intentions. Repurchasing in service industry resembles retaining the old customers, which is labeled as retention. In order to attain new customers and retain the old one, the service quality is the significant instrument that can be used, which is also receiving importance in Higher Education (Ilyasi et al., 2003).

The willingness to recommend and willingness to choose the institution where the service was delivered repeatedly, were implied in some literature as aspects of loyalty construct (e. g., Caruana, 2002; Purgailis \& Zaksa, 2012; Hassan et al., 2013). In this regard, Henning-Thurau et al. (2001) postulate several reasons for the importance of students' loyalty in educational institutions that included retaining students, and recommending the institution, which are broadly considered as a vital success factor in service industry.

Further evidence was reported in Higher Education literature by De Jager and Gbadamosi (2010), where perceived service quality was significantly correlated with students' intention to leave the university.

The effect of perceived service quality on these two behavior intentions were examined throughout the dimensions of service quality. For instance, Hassan et al. (2013) reported significant effects of each dimension of perceived service quality on customer loyalty in the banking industry.

Students' intentions to leave their university studies can be seen as a result of their experience in their universities or other reasons.

Due to several reasons including their experience in their universities, some students may have intentions to leave their university studies. Therefore, it can be worthy to control for these intentions to verify the effect of perceived quality on behavior intentions.

Similarly, a significant difference in the perception of the five service quality dimensions between the senior and 
younger participants based on the SERVQUAL was reported repeatedly (e.g., Lee et al., 2012). On the other hand, age has some influence on behavior intentions (e.g., Salanova et al., 2005; Realo \& Dobewall 2011; Koni et al., 2013). This applies to study level, as a significant relationship was reported with behavior intentions where students tend to make the decision to transfer to other institutions normally during the first and second year of study (Koni et al., 2013).

Therefore, to clarify the effect of perceived service quality on behavior intentions, age and study level will be controlled for in determining the effect of perceived service quality on behavior intentions. Further, according to the previous argument for the first hypothesis, gender will be controlled for as well. Thus, the following hypotheses are proposed.

$\mathrm{H}_{\mathrm{A}} 3$ : After controlling for personal characteristics (age, gender, education level, educational attainment, and intention to leave university study), the perceived service quality affect the students' intentions of recommending to study at their university.

$\mathrm{H}_{\mathrm{A}} 4$ : After controlling for personal characteristics (age, gender, study level, educational attainment, and intention to leave university study), the five dimensions of service quality affect the students' intentions of recommending to study at their university.

$\mathrm{H}_{\mathrm{A}}$ 5: After controlling for personal characteristics (age, gender, study level, educational attainment, and intention to leave university study), the perceived service quality affects the students' intentions of moving to study at another university.

$\mathrm{H}_{\mathrm{A}}$ 6: After controlling for personal characteristics (age, gender, study level, study grade, and intention to leave university study), the five dimensions of service quality affect the students' intentions of moving to study at another university.

\section{Methodology}

\subsection{Scale Measurement}

\subsubsection{Perceived Service Quality}

This study aims to investigate the impact of perceived service quality on students' behavior intentions in a Jordanian governmental university. A modified version of SERVQUAL instrument was used. SERVQUAL scale, suggested by Parasuraman et al. (1988) is a clear evidence in higher education literature. The SERVQUAL tool, which is effective in measuring service quality in the higher education environment, is helpful in preparing guidelines for changing weaknesses to strengths (Harris, 2002; Angell et al., 2008; Yang, 2008).

Therefore, dimensions of SERVQUAL used to measure students' perceptions of service quality at University were as follows:

Tangibles: include Physical facilities, equipment, and appearance of personnel;

Reliability: refers to ability to perform the promised service dependably and accurately Responsiveness: is Willingness to help customers and provide prompt service;

Assurance: is knowledge and courtesy of employees and their ability to inspire trust and confidence;

Empathy: caring, individualized attention the firm provides to its Customers.

Main Source: Parasuraman, Zeithaml, and Berry (1988).

The questionnaire was based on only service perception, recommended by Nadiria et al. (2009). Hill (1995) recognized the difficulty of measuring expectations for students. Hill confirmed that many students do not even know what expectations they have, or which expectations they had about the service provided Purgailis and Zaksa (2012).

The negative empirical findings concerning the measurement of expectations led to some doubt about its value Nadiri at al. (2009). Several researchers indicated that measurement of expectations does not provide unique information for estimating service quality, and they argue that performance-only assessment has already taken into account much of this information (Babakus \& Boller, 1992; Cronin \& Taylor, 1992)

This measurement is applied and used by many scholars in different studies measuring service quality in higher education (e. g., Soteriou \& Zenios, 1997; Arambewela \& Hall, 2006; Yeo, 2009; Nadiri et al., 2009; Ibrahim et al., 2013).

As the original, all the items of the measurements were assessed with seven -point Likert - Type scale to measure the students perception ranging from (1) Strongly disagree to (7) Strongly agree. This technique is used 
by different researchers (e. g., Arambewela \& Hall, 2006; Khodayari \& Khodayari, 2011; Dado et al., 2012; Ilyasi et al., 2013).

\subsubsection{Students' Behavior Intentions}

Single-item measure was used for each of the two variables which relate students' behavior intentions. Rossiter, (2002) has strongly argued that intentions should not be captured with multiple-item scales. This variable measure through two questions based on extensive literature (e. g., Zeithaml et al., 1996) these questions are as follows:

Do you intend to recommend your university to the new students?

Do you intend to move to another university?

These two items were assessed with seven -point Likert - Type scale to measure from (1) Strongly disagree to (7) Strongly agree. This technique is used for matching the first variable.

\subsubsection{Intentions to Leave the Study}

A single-item measure was used to assess this variable with seven -point Likert - Type scale ranging from (1) Strongly disagree to (7) Strongly agree. This technique is used for matching the first and second variable. this question was as follows:

Do you intend to leave the study?

\subsection{Population and Sampling}

This study was conducted in a Jordanian governmental university that has 8408 students at the time of the study. A stratified systemic random sample of 841 studentswas surveyed yielding 572 participants with $68 \%$ response rate. The method of selecting participants and the response rate would enable considering the sample as representative. Females were 311 whereas males were 230 and 31 respondents did not report their gender. Their ages varied between 18 and 40 with a mean of 20.62 and standard deviation of 2.298 and 79 who did not report their age.

\section{Results and Discussion}

\subsection{Reliability}

Cronbach's coefficient alpha was used to test reliability of the overall service quality dimensions and of each dimension. The reliability of overall service quality scale was found .775 where the reliability of each dimension of service is as follows: tangibles (.692) reliability (.672), responsiveness (.660), assurance (.648) and empathy (.653). These values are above the generally agreed upon lower limit of 0.60 (Hair et al., 2006).

\subsection{Hypotheses Testing}

The researchers applied the hierarchical regression analysis approach to test the emerging hypotheses.

$H_{A} 1$ : There are differences in the perceived service quality between the two genders.

The results of t-test show that there is no significant difference between males and females regarding perceived quality $(p=180)$. The 95\% Confidence Interval of the difference is between -0.221 and 0.042 . Details of the means and their standard deviations regarding behavior intentions and dimensions of perceived service quality are presented in Table (1).

$H_{A} 2$ : There are differences in five dimensions of service quality between the two genders.

The results of t-test show that males assessed the tangibility dimension of service quality significantly $(\mathrm{p}=000)$ higher than females. Nonetheless, differences between the two genders regarding the other dimensions were insignificant: reliability $(\mathrm{p}=.415)$, responsiveness $(\mathrm{p}=0.156)$, assurance $(\mathrm{p}=.849)$, and empathy $(\mathrm{p}=.628)$ ). The 95\% Confidence Intervals of the difference for these dimensions are between $(-0.311$ and 0.128$),(-0.417$ and $0.067),(-0.191$ and 0.232$)$, and (-0.151 and 0.262), respectively. Details of the means and their standard deviations regarding behavior intentions and dimensions of perceived service quality are presented in Table (1).

These results are consistent with the earlier discussion in literature review, especially concerning the tangibility dimension and the direction of differences Ross et al. (1999). Nonetheless, the differences in the other dimension are not significant, and thus this is not in line with Lee et al. (2012). 
Table 1. Statistical results of means and standard deviations

\begin{tabular}{|c|c|c|c|c|c|c|c|c|c|c|}
\hline & & Female & & & Male & & Missing & & Total & \\
\hline & $\mathrm{N}$ & Mean & SD & $\mathrm{N}$ & Mean & SD & $\mathrm{N}$ & $\mathrm{N}$ & Mean & SD \\
\hline $\begin{array}{l}\text { Students' intentions of moving to study at } \\
\text { another university }\end{array}$ & 307 & 3.14 & 2.437 & 223 & 3.60 & 2.489 & 27 & 557 & 3.38 & 2.48 \\
\hline $\begin{array}{l}\text { Students' intentions of recommending to study } \\
\text { at their university }\end{array}$ & 301 & 3.99 & 2.058 & 223 & 4.00 & 2.011 & 27 & 551 & 4 & 2.048 \\
\hline Student's intension to leave university study & 301 & 1.69 & 1.494 & 223 & 1.75 & 1.591 & 27 & 551 & 1.74 & 1.573 \\
\hline Perceived service quality & 311 & 4.44 & .799 & 230 & 4.53 & .728 & 30 & 571 & 4.48 & .773 \\
\hline Reliability & 296 & 5.10 & 1.271 & 217 & 5.19 & 1.220 & 28 & 541 & 5.14 & 1.25 \\
\hline Tangibility & 278 & 4.21 & 1.235 & 217 & 4.63 & 1.070 & 25 & 520 & 4.41 & 1.195 \\
\hline Responsiveness & 274 & 3.32 & 1.360 & 217 & 3.49 & 1.347 & 26 & 517 & 3.4 & 1.38 \\
\hline Assurance & 279 & 5.17 & 1.249 & 215 & 5.15 & 1.094 & 28 & 522 & 5.16 & 1.199 \\
\hline Empathy & 282 & 4.40 & 1.223 & 215 & 4.35 & 1.121 & 25 & 522 & 4.38 & 1.195 \\
\hline
\end{tabular}

Note. $\mathrm{N}=$ number, $\mathrm{SD}=$ standard deviation.

Table 1 shows the mean and standard deviation values for perceived service quality and all the dimensions of service quality. The table also, shows these values for males and females. Regarding tangibility dimension, the table shows that the mean for males was (4.63) while for females it was (4.21) this result means that the evaluation of female tangible services at the university was low compared with males evaluation.

$H_{A} 3$ : After controlling for personal characteristics (age, gender, study level, educational attainment, and intention to leave university study), the perceived service quality affects the students' intentions of recommending to study at their university.

A hierarchical regression was used to test HA3. As shown in table 2, the results of hierarchical regression show that the control variables explain $1.9 \%(\mathrm{p}=0.174)$ of students' intentions of recommending, whereas the dimensions of service quality explain $8.2 \%(\mathrm{p}=0.000)$. The values of standardized beta $(b)$ show that perceived service quality $(b=0.291, p=0.000)$ significantly affect students' intention of recommending. The value of Durbin-Watson shows that there is no autocorrelation between residuals.

Table 2. Statistical results of testing HA3

\begin{tabular}{|c|c|c|c|c|}
\hline \multirow{3}{*}{$\begin{array}{l}\text { Dependent variable } \\
\text { Students' intentions of recommending to study at their } \\
\text { university }\end{array}$} & \multicolumn{2}{|c|}{ Standardized Coefficients } & \multicolumn{2}{|c|}{ Significance } \\
\hline & \multicolumn{2}{|c|}{ B } & \multicolumn{2}{|c|}{$P$} \\
\hline & step1 & step2 & step1 & step2 \\
\hline (Constant) & & & .000 & .594 \\
\hline Education attainment & .011 & .021 & .829 & .667 \\
\hline Study level & -.128 & -.096 & .020 & .068 \\
\hline Gender & -.032 & -.042 & .528 & .385 \\
\hline Age & .011 & .012 & .846 & .821 \\
\hline Student's intension to leave university study & -.026 & .022 & .594 & .648 \\
\hline Perceived service quality & & .291 & & .000 \\
\hline change in R2 / Durbin-Watson & 0.019 & 0.082 & & \\
\hline
\end{tabular}

$H_{A} 4$ : After controlling for personal characteristics (age, gender, study level, educational attainment, and intention to leave university study), the five dimensions of service quality affect the students' intentions of recommending to study at their university.

A hierarchical regression was used to test $\mathrm{H}_{\mathrm{A}} 4$. As shown in table 3, the results of hierarchical regression show that the control variables explain $3.5 \%(p=0.001)$ of students' intentions of recommending, whereas the 
dimensions of service quality explain $15 \%(p=0.001)$. The values of standardized beta $(b)$ show that out of the five dimension of service quality, only Tangibility $(b=0.209, p=0.001)$ and Assurance $(b=0.163, p=0.021)$ significantly affect students' intention of recommending. The value of Durbin-Watson shows that there is no autocorrelation between residuals

Table 3. Statistical results of testing $\mathrm{H}_{\mathrm{A}} 4$

\begin{tabular}{|c|c|c|c|c|}
\hline \multirow{3}{*}{$\begin{array}{l}\text { Dependent variable } \\
\text { Students' intentions of recommending to study at their } \\
\text { university }\end{array}$} & \multicolumn{2}{|c|}{ Standardized Coefficients } & \multicolumn{2}{|c|}{ Significance } \\
\hline & \multicolumn{2}{|c|}{ B } & \multicolumn{2}{|c|}{$P$} \\
\hline & Step1 & Step2 & Step1 & Step2 \\
\hline (Constant) & & & 0.008 & 0.809 \\
\hline Education attainment & 0.003 & 0.027 & 0.956 & 0.618 \\
\hline Study level & -0.154 & -0.1 & 0.016 & 0.093 \\
\hline Gender & -0.018 & -0.036 & 0.75 & 0.501 \\
\hline Age & 0.077 & 0.031 & 0.222 & 0.597 \\
\hline Student's intension to leave university study & -0.117 & -0.092 & 0.041 & 0.098 \\
\hline Reliability & & 0.113 & & 0.108 \\
\hline Tangibility & & 0.209 & & 0.001 \\
\hline Responsiveness & & -0.032 & & 0.591 \\
\hline Assurance & & 0.163 & & 0.021 \\
\hline Empathy & & 0.056 & & 0.331 \\
\hline Change in R2 / Durbin-Watson & 0.035 & 0.15 & 1.841 & \\
\hline
\end{tabular}

The results of testing $\mathrm{H} 3$ and $\mathrm{H} 4$ are support the previous arguments presented in literature review, and consistent with the earlier discussion (Zeithaml et al., 1996; Bloemer et al., 1999).

$H_{A}$ 5: After controlling for personal characteristics (age, gender, study level, educational attainment, and intention to leave university study), the perceived service quality affect the students' intentions of moving to study at another university.

A hierarchical regression was used to test $\mathrm{H}_{\mathrm{A}} 5$. As shown in table 4 , the results of hierarchical regression show that the control variables explain $8.7 \%(p=0.000)$ of students' intentions of moving to study at another university, whereas the dimensions of service quality explain $4.2 \%(p=0.000)$. The values of standardized beta $(b)$ show that perceived service quality $(b=-0.209, p=0.000)$ significantly affect students' intentions of moving to study at another university. The value of Durbin-Watson shows that there is no autocorrelation between residuals.

Table 4. Statistical results of testing HA5

\begin{tabular}{|c|c|c|c|c|}
\hline \multirow{3}{*}{$\begin{array}{l}\text { Dependent variable } \\
\text { Students' intentions of moving to study at another } \\
\text { university }\end{array}$} & \multicolumn{2}{|c|}{ Standardized Coefficients } & \multicolumn{2}{|l|}{ Significance } \\
\hline & \multicolumn{2}{|c|}{$\mathrm{B}$} & \multicolumn{2}{|c|}{$P$} \\
\hline & Step1 & Step2 & Step1 & Step2 \\
\hline (Constant) & & & .000 & .000 \\
\hline Education attainment & -.047 & -.054 & .330 & .249 \\
\hline Study level & .004 & -.020 & .946 & .701 \\
\hline Gender & .120 & .127 & .013 & .007 \\
\hline Age & -.187 & -.188 & .000 & .000 \\
\hline Student's intension to leave university study & .205 & .170 & .000 & .000 \\
\hline Perceived service quality & & -.209 & & .000 \\
\hline Change in R2 / Durbin-Watson & .087 & .042 & & \\
\hline
\end{tabular}


HA6: After controlling for personal characteristics (age, gender, study level, study grade, and intention to leave university study), the five dimensions of service quality affect the students' intentions of moving to study at another university.

A hierarchical regression was used to test $\mathrm{H}_{\mathrm{A}} 6$. As shown in table 5, the results of hierarchical regression show that the control variables explain $13.3 \%$ of students' intentions of moving, whereas the dimensions of service quality explain $5.5 \%$. The values of standardized beta (b) show that out of the five dimension of service quality, only Assurance $(\mathrm{b}=-0.185, p=0.008)$ and Empathy $(\mathrm{b}=0.131, p=0.023)$ significantly affect students' intention of moving. The value of Durbin-Watson shows that there is no autocorrelation between residuals.

Table 5. Statistical results of testing $\mathrm{H}_{\mathrm{A}} 6$

\begin{tabular}{|c|c|c|c|c|}
\hline \multirow{3}{*}{$\begin{array}{l}\text { Students' intentions of moving to study at another } \\
\text { university }\end{array}$} & \multicolumn{2}{|c|}{ Standardized Coefficients } & \multicolumn{2}{|c|}{ Significance } \\
\hline & \multicolumn{2}{|c|}{ B } & \multicolumn{2}{|c|}{$P$} \\
\hline & Step1 & Step2 & Step1 & Step2 \\
\hline (Constant) & & & 0.000 & 0.000 \\
\hline Education attainment & -0.107 & -0.118 & 0.051 & 0.029 \\
\hline Study level & 0.007 & -0.017 & 0.913 & 0.768 \\
\hline Gender & 0.091 & 0.089 & 0.094 & 0.099 \\
\hline Age & -0.264 & -0.25 & 0.000 & 0.000 \\
\hline Student's intension to leave university study & 0.222 & 0.155 & 0.000 & 0.005 \\
\hline Reliability & & -0.014 & & 0.847 \\
\hline Tangibility & & 0.017 & & 0.787 \\
\hline Responsiveness & & 0.029 & & 0.620 \\
\hline Assurance & & -0.185 & & 0.008 \\
\hline Empathy & & 0.131 & & 0.023 \\
\hline Change in R2 / Durbin-Watson & 0.133 & 0.056 & & \\
\hline
\end{tabular}

The results of testing $\mathrm{H} 5$ and $\mathrm{H} 6$ are support the previous arguments presented in literature review, and consistent with the earlier discussion (Fen \& Lian, 2005; Nadiri \& Hussain, 2005; Negi, 2009; Alexandris et al., 2002; Ranaweera \& Neely, 2003).

\section{Conclusions and Implications}

Depending on the hypotheses testing of the study results can provide the following conclusions:

The results show that there were no differences in the perceived service quality with respect to gender. This result is applied to the studied services quality dimensions except tangibility, where the male students' assessment of this dimension is higher than females assessment.

The results showed that the perceived service quality at the university has an impact on behavioral intentions of students regarding the recommendation for new students to study at their university and the intention to move to another university. For new students, tangible dimension is the most influential dimension and followed by the assurance dimension. Other dimensions had no statistically significant effect. As regard the intention to transfer to another university, assurance was the most influential dimension followed by empathy, whereas the rest of the service quality dimensions studied had no statistically significant effect.

\subsection{Managerial Implications}

As there is a difference between male and female students in their perception to tangibles which is due to variation in interest, where females' assessment was lower than the males assessment, Therefore, it can be recommended to the university administration to focus on the tangible dimensions of the university services associated with females. The second conclusion confirms a tangibility effect for new students. This emphasizes the importance of focusing on this dimension. The university administration should pay attention to the tangible dimensions of the university and give more attention to the tangible dimension services provided to students at 
the university to this dimension of the contribution of the study exhibited in attracting new students. There is a need to give adequate attention by the university administration to assurance because of its impact on attracting new students. In addition to the impact of this dimension in maintaining the current students, there is a need to focus on empathy dimension to maintain the current students.

\subsection{Research Limitations and Recommendations}

In terms of measurement issues, although the SERVQUAL is a measure used in this study that is recommended for use in the field of Higher Education, but there are other methods that directly measure academic quality which were not used in this study. For future studies, other measurements should be used along with the SERVQUAL, such Owlia and Aspinwall (1996).

\section{References}

Abdullah, F. (2006). The development of HEdPERF: A new measuring instrument of service quality for the higher education sector. International Journal of Consumer Studies, 30(6), 569-581. http://dx.doi.org/10.1111/j.1470-6431.2005.00480.x

Alexandris, K., Dimitradis, N., \& Markata D. (2002). Can perceptions of service quality predict behavioral intentions? An exploratory study in the hotel sector in Greece. Managing Service Quality, 12(4), 224-23. http://dx.doi.org/10.1108/09604520210434839

Angell, R. J., Heffernan, T. W., \& Megicks, P. (2008). Service quality in postgraduate education. Quality Assurance in Education, 16(3), 236-254. http://dx.doi.org/ 10.1108/09684880810886259

Arambewela, R., \& Hall, J. (2006). A comparative analysis of international education satisfaction using SERVQUAL. Journal of Services Research, 6(3), 141-163. http://hdl.handle.net/10536/DRO/DU:30003511

Athiyaman, A. (1997). Linking student satisfaction and service quality perceptions: The case of university education. European Journal of Marketing, 31, 528-540. http://dx.doi.org/10.1108/03090569710176655

Babakus, E., \& Boller, G. W. (1992). An empirical assessment of the servqual scale. Journal of Business Research, 24(3), 253-268. http://dx.doi.org/10.1016/0148-2963(92)90022-4

Baron, S., Harris, K., \& Hilton, T. (2009). Services marketing: Text and cases (3rd ed.). Basingstoke: Palgrave Macmillan.

Bloemer, J., De Ruyter, K., \& Wetzels, M. (1999). Linking perceived service quality and service loyalty: A multi-dimensional perspective. European Journal of Marketing, 33(11), 1082-1106. http://dx.doi.org/10.1108/03090569910292285

Bontis, N., Booker, L., \& Serenko, A. (2007). The mediating effect of organizational reputation on customer loyalty and service recommendation in the banking industry, Management Decision, 45(9), 1426-1445. http://dx.doi.org/10.1108/00251740710828681

Boulding, W., Kalra, A., Staelin, R., \& Zeithaml, V. A. (1993). A dynamic process model of service quality: From expectations to behavioral intentions. Journal of Marketing Research, 30, 7-27. http://dx.doi.org/10.2307/3172510

Bowie, D., \& Buttle, F. (2004). Hospitality marketing: An introduction. Burlington, MA: Elsevier.

Brochado, A. (2009). Comparing alternative instruments to measure service quality in higher education. Qual. Assu. in Edu., 17, 174-190. http://dx.doi.org/10.1108/09684880910951381

Buttle, F. (1996). SERVQUAL: Review, critique, research agenda. European Journal of Marketing, 30(1), 8-32. http://dx.doi.org/10.1108/03090569610105762

Caruana, A. (2002). Service loyalty: The effects of service quality and the mediating role of customer satisfaction. European Journal of Marketing, 36(7/8), 811-828. http://dx.doi.org/10.1108/03090560210430818

Cheng, Y. C., \& Tam, W. M. (1997). Multi-models of quality in education. Quality Assurance in Education, 5(1), 22-31. http://dx.doi.org/10.1108/09684889710156558

Cronin, J. J., \& Taylor, S. A. (1992). Measuring service quality: Reexamination and extension. Journal of Marketing, 56, 55-68. http://dx.doi.org/10.2307/1252296

Dado, J., Petrovicova, J. T., Cuzovic, S., \& Rajic, T. (2012). An empirical examiniation of the relationships between service quality, satisfaction and behavioral intentions in the higher education setting. Serbian Journal of Management, 7(2), 203-218. http://dx.doi.org/10.5937/sjm.v7i2.1245 
De Jager, J., \& Gbadamosi, G. (2010). Specific remedy for specific problem: Measuring service quality in South African higher education. Higher Education, 60(3), 251-267. http://dx.doi.org/10.1007/s10734-009-9298-6

De Ruyter, K., Wetzels, M., \& Bloemer, J. (1998). On the relationship between perceived service quality, service loyalty and switching costs. International Journal of Service Industry Management, 9(5), 436-453. http://dx.doi.org/10.1108/09564239810238848

DeShields, Jr, O. W., Kara, A., \& Kaynak, E. (2005). Determinants of business student satisfaction and retention in higher education: Applying Herzberg's two-factor theory. International Journal of Educational Management, 19(2), 128-139. Emerald Group Publishing Limited. http://dx.doi.org/10.1108/09513540510582426

Eshghi, A., Roy, S. K., \& Ganguli, S. (2008). Service quality and customer satisfaction: An empirical investigation in Indian mobile Telecommunications services. Marketing Management Journal, 18(2), 119-144.

Fen, Y., \& Lian, K. (2005).Service quality and customer satisfaction: Antecedents of customers' re-patronage intentions. Sunway Academic. Journal, 4(1), 60-73.

Ghylin, K. M., Green, B. D., Drury, C. G., Chen, J., Schultz, J. L., Uggirala, A., Abraham, J. K., \& Lawson, T. A. (2008). Clarifying the dimensions of four concepts of quality. Theoretical Issues in Ergonomics Science, 9(1), 73-94. http://dx.doi.org/10.1080/14639220600857639

Gracia, E., Bakker, A. B., \& Grau, R. M. (2011). The connection between customer quality evaluations and loyalty. Cornell Hospitality Quarterly, 52(4), 458-465. http://dx.doi.org/10.1177/1938965510395379

Ha, J., \& Jang, S. (2012). The effects of dining atmospherics on behavioral intentions through quality perception. Journal of Services Marketing, 26(3), 204-215. http://dx.doi.org/10.1108/08876041211224004

Hair, J. F., Black, W. C., Babin, B. J., Anderson, R. E., \& Tatham, R. L. (2006). Multivariate data analysis (6th ed.). New Jersey: Pearson Prentice Hall, Upper Saddle River.

Ham, C., \& Hayduk, S. (2003). Gaining competitive advantages in higher education: Analyzing the gap between expectations and perception of service quality. International Journal of Value-Based Management, 16(3), 223-242. http://dx.doi.org/10.1023/A:1025882025665

Harris, B. L. (2002). A study of service quality: Gap analysis of expectations versus performance perceptions of junior, senior, and graduate students. Unpublished $\mathrm{PhD}$ thesis, University of Alabama.

Harvey, L. (2001). Student feedback: A report to the higher education funding council for England. Research report, Centre for Research into Quality, The University of Central England, Birmingham, United Kingdom.

Harvey, L., \& Green, D. (1993). Defining quality. Assessment \& Evaluation in Higher Education, 18(1), 9-34. http://dx.doi.org/10.1080/0260293930180102

Hassan, M., Malik, A., Imran, M., Hasnain, A., \& Abbas, J. (2013). Relationships among customers' perceived service quality, satisfaction and loyalty in the retail banking sector of Pakistan. World Applied Sciences Journal, 24(8), 1020-1030.

Hennig-Thurau, T., Langer, M., \& Hansen, U. (2001). Modeling and managing student loyalty: An approach based on the concept of relationship quality. Journal of Service Research, 3(4), 331-344. http://dx.doi.org/10.1177/109467050134006

Hill, F. (1995). Managing service quality in higher education: The role of the student as primary consumer. Quality Assurance in Education, 3(3), 10-21. http://dx.doi.org/10.1080/1353832950010107

Ibrahim, E., Wang, L, W., \& Hassan, A. (2013). Expectations and perceptions of overseas students towards service quality of higher education institutions in Scotland. International Business Research, 6(6), 20-30. http://dx.doi.org/10.5539/ibr.v6n6p20

Ilyasi, A., Nasir, H., Hussain, F., Malik, M. R., Munir, S., \& Sarwar, Z. (2013). Evaluating business schools service quality using SERVQUAL model. Journal of Basic and Applied, 3(5), 710-716.

Khodayari, F., \& Khodayari, B. (2011). Service quality in higher education case study: Measuring service quality of Islamic Azad University, Firoozkooh branch. Interdisciplinary Journal of Research in Business, 1(9), 38-46. http://www.idjrb.com/articlepdf/idjrb9n1p5u.pdf

Koni, A., Zainal, K., \& Ibrahim, M. (2013). An assessment of the services quality of Palestine higher education. International Education Studies, 6(2), 33-48. http://dx.doi.org/10.5539/ies.v6n2p33 
Ladhari, R. (2009). A review of twenty years of SERVQUAL research. International Journal of Quality and Service Sciences, 1(2), 172-198. http://dx.doi.org/10.1108/17566690910971445

Lau, L. K. (2003). Institutional factors affecting student retention. Education, 124(1), 126-136.

Lee J. W., \& Tai, S. W. (2008). Critical factors affecting customer satisfaction and higher education in Kazakhstanv. International Journal of Management in Education, 2, 46-59. http://dx.doi.org/10.1504/IJMIE.2008.016230

Lee, M., \& Cunningham, L. F. (2001). A cost/benefit approach to understanding service loyalty. Journal of Services Marketing, 15(2), 113-130. http://dx.doi.org/10.1108/08876040110387917

Lee, T., Cho, H., \& Ahn, T. (2012). Senior citizen satisfaction with restaurant service quality. Journal of Hospitality Marketing \& Management, 21(2), 215-226. http://dx.doi.org/ 10.1080/19368623.2010.520822

Long, P., Tricker, T., Rangecroft, M., \& Gilroy, P. (1999). Measuring the satisfaction gap: Education in the market-place. Total Quality Management, 10(4/5), 772-778. http://dx.doi.org/ 10.1080/0954412997794

Nadiri, H., \& Hussain, K. (2005). Perceptions of service quality in North Cyprus hotels. International Journal of Contemporary Hospitality Management, 17(6), 469-480. http://dx.doi.org/10.1108/09596110510612112

Nadiri, H., Kandampully, J., \& Hussain, K. (2009). Students' perceptions of service quality in higher education. Total Quality Management, 20(5), 523-535. http://dx.doi.org/10.1080/14783360902863713

Negi, R. (2009). Determining customer satisfaction through perceived service quality: A study of Ethiopian mobile users. International Journal of Mobile Marketing, 4(1), 31-38.

Owlia, M., \& Aspinwall, E. (1996). A framework for the dimensions of quality in higher education. Quality Assurance in Education, 4(2), 12-20. http://dx.doi.org/10.1108/09684889610116012

Parasuraman, A., Zeithaml, V. A., \& Berry, L. L. (1985). A conceptual model of service quality and its implications for future research. Journal of Marketing, 49, 41-50. http://dx.doi.org/10.2307/1251430

Parasuraman, A., Zeithaml, V. A., \& Berry, L. L. (1988). SERVQUAL: A multiple item scale for measuring consumer perceptions of service quality. Journal of Retailing, 64(1), 12-24. http://dx.doi.org/10.2307/1251430

Parasuraman, A., Zeithaml, V. A., \& Berry, L. L. (1994). Reassessment of expectations as a comparison standard in measuring service quality: Implications for further research. Journal of Marketing, 58, 111-124. http://dx.doi.org/10.2307/1252255

Purgailis. M., \& Zaksa, K. (2012). The impact of perceived service quality on student loyalty in higher education institutions. Journal of Business Management, 6, 138-152.

Ranaweera, C., \& Neely, A. (2003). Some moderating effects on the service quality-customer retention link. International Journal of Operations \& Production Management, 23(2), 230-248. http://dx.doi.org/10.1108/01443570310458474

Realo, A., \& Dobewall, H. (2011). Does life satisfaction change with age? A comparison of Estonia, Finland, Latvia, and Sweden. Journal of Research in Personality, 45(3), 297-308. http://dx.doi.org/10.1016/j.jrp.2011.03.004

Rossiter, J. R. (2002). The C-OAR-SE procedure for scale development in marketing. International Journal of Research in Marketing, 19(4), 305-335. http://dx.doi.org/ 10.1016/S0167- 8116(02)00097-6

Rowley, J. (1997). Beyond service quality dimensions in higher education and towards a service contract. Quality Assurance in Education, 5(1), 7-14. http://dx.doi.org/10.1108/09684889710156530

Saadati, S. (2012). The measurement education services quality payam noor university of garmsarwith using of servqual model. Journal of Basic Applied, 2(6), 6337-6343.

Salanova, M., Agut, S., \& Peiro, J. (2005). Linking organizational resources and work engagement to employee performance and customer loyalty: The mediation of service climate. Journal of Applied Psychology, 9(6), 12-17. http://dx.doi.org/10.1037/0021-9010.90.6.1217

Seymour, D. T. (1992). It's all in the attitude, on Q: Causing quality in higher education. American Council on Education and Macmillan Publishing Company, 126-141.

Snipes, R. L., Thomson, N. F., \& Oswald, S. L. (2006). Gender bias in customer evaluations of service quality: An empirical investigation. Journal of Services Marketing, 20(4), 274-284. 
http://dx.doi.org/10.1108/08876040610674616

Soteriou, A., \& Zenios, S. A. (1997). Efficiency, profitability and quality of banking services. International Journal of Bank Marketing, 18(5), 97-128.

Tahmouri, A., Khosravi, M. R., Akbari, M., Jalali, A. S., Hassanpoor, R., \& Saberhosseini, S. S. (2010). Servqual model and measurement of service quality. Journal of Basic and Applied, 2(6), 5545-5549.

Takalo, S., Abadi, A., S., Vesal, S., Mirzaei, A., \& Nawaser, K. (2013). Fuzzy failure analysis: A new approach to service quality analysis in higher education institutions (Case study: Vali-e-asr University of Rafsanjan-Iran). International Education Studies, 6(9), 93-106. http://dx.doi.org/10.5539/ies.v6n9p93

Temizer, L., \& Turkyilmaz, A. (2012). Implementation of student satisfaction index model in higher education institutions. Procedia, Social and Behavioral Sciences, 46, 3802-3806. http://dx.doi.org/10.1016/j.sbspro.2012.06.150

Yang, L. M. (2008). An examination of education service quality at collegiate physical education departments in Taiwan: Using a gap analysis approach. Unpublished $\mathrm{PhD}$ thesis, United States Sports Academy.

Yeo, R. (2009). Service quality ideals in a competitive tertiary environment. International Journal of Educational Research, 62-76. http://dx.doi.org/10.1016/j.ijer.2009.03.004

Zeithaml, V. A., Berry, L. L., \& Parasuraman, A. (1996). The behavioral consequences of service quality. Journal of Marketing, 60(2), 31-46. http://dx.doi.org/10.2307/1251929

Zineldin, M. (2007). The quality of higher education and student satisfaction self assessment and review process a trm philosophy and 5Qs model. Paper presented at Second International Conference Education, Economics, and Law: Traditions and Innovations. Vaxjo University, Sweden. Retrieved from http://tempus.ulim.md/proj_dis.php

\section{Copyrights}

Copyright for this article is retained by the author(s), with first publication rights granted to the journal.

This is an open-access article distributed under the terms and conditions of the Creative Commons Attribution license (http://creativecommons.org/licenses/by/3.0/). 